DOI 10.31509/2658-607x-2020-3-3-1-25

\title{
SCIENCE IN THE VANGUARD OF RETHINKING THE ROLE OF FORESTS IN THE THIRD MILLENNIUM: COMMENTS ON THE DRAFT CONCEPT OF THE FEDERAL LAW "FOREST CODE OF THE RUSSIAN FEDERATION"
}

\author{
(C) 2020 A.M. Makarieva ${ }^{*}$, A.V. Nefiodov ${ }^{*}$, V.E. Morozov $^{2}$, A.A. Aleynikov ${ }^{3}$, R.G. Vasilov ${ }^{4}$ \\ ${ }^{1}$ B.P. Konstantinov Petersburg Nuclear Physics Institute, Russia, 188300, Leningrad district, \\ Orlova Roscha, 1 \\ ${ }^{2}$ Public Council of Federal Forestry Agency, Russia, 115184 Moscow, ul. Pyatnitskaya, 59/19 \\ ${ }^{3}$ Center for Forest Ecology and Productivity, Russian Academy of Sciences \\ Russia, 117997 Moscow, ul. Profsoyuznaya, 84/32, bld. 14 \\ ${ }^{4}$ Yu.A. Ovchinnikov Russian Society of Biotechnologists \\ Russia, 119071 Moscow, Leninsky pr., 33, bld. 2 \\ *E-mail: ammakarieva@gmail.com; anef@thd.pnpi.spb.ru
}

Received: 01.10.2020

Accepted 19.10.2020

In this work, in the light of the latest scientific data, multiple aspects of the regulatory influence of forest ecosystems on climate are considered from the standpoint of the concept of biotic regulation of the environment: carbon absorption in the biomass of trees and soil, regulation of local temperature regime through the transpiration and reflectivity of forest cover, regulation of continental transport of atmospheric moisture and cloudiness. It is shown that under conditions of increasing climatic destabilization, the value of the climate-regulating function of forests and, in particular, its aspects associated with the water cycle, rapidly increases in comparison with the traditional economic functions of the forest. The Forest Code, as the main document regulating the impact of Russian citizens on the forest, should take into account the dynamically developing situation and assign a special role to climate-regulating forests. Considering that natural forest ecosystems have finite stability and climate-regulating potential, which commercially-scaled timber harvesting and other methods of exploitation can completely destroy, it is proposed to achieve a balance between the economic and climate-regulating functions of forests through their spatial delineation. Economic activity must be carried out intensively in previously developed territories where forests have been perturbed beyond their self-recovery threshold. Intact forests, performing a climate-regulating function, are proposed to be separated into a distinct legal category, subject only to protection and intensive study. It is shown that the advancement of the category of climate-regulating forests in the international climate agenda is vital for the protection of the national interests of Russia.

Keywords: biotic regulation of the environment, climate, carbon, water regime, clouds, biota, biogens, ecosystems, fire, climate-regulating forests, intact forest landscapes

\section{Introduction}

Modern science is generating new knowledge - and modern world is transforming - at an unprecedented rate. This necessitates an adequate flexibility of policies in all spheres of the society's functioning. A successful policy should ideally anticipate the relevant trends, be sensitive to the flux of new information and be ready and able to transform on-the-fly. Today, among the most important and relevant for the human well-being are the concepts about climate stability and the role vegetation cover in its maintenance.

In this context, it is definitely positive that a new notion - that of the climate-regulating function of forests - has been included into the 
draft concept of the federal law "Forest Code of Russian Federation" prepared by the working group of the Research Board on Forests of Russian Academy of Sciences (Gagarin, 2020). In this commentary, we briefly outline our vision of how recent scientific advancements define the meaning of the new notion as well as its subsequent development, which, in our opinion, should lead to the establishment of the climateregulating least-disturbed forests as a distinct legal category, subject to research and protection at the level of a high-priority national program. We argue that introducing this category is not just a key measure to ensure the environmental security of our country in the long-term but that it is also in line with Russia's current economic and political interests in the modern world where the climate agenda links intricately to both economics and politics.

Forest impact on climate: Critical factors and uncertainties

Carbon: Accumulation in the soil of leastdisturbed forests?

Modern civilization consumes energy from two main sources - fossil fuels and biomass. Fossil fuel burning emits to the atmosphere about $9 \mathrm{GtC} / \mathrm{yr}$, to which at least $2 \mathrm{GtC} / \mathrm{yr}$ is added from the destruction of the organic stores of the biosphere (soil degradation and deforestation) (data are given to the accuracy of $0.5 \mathrm{GtC} / \mathrm{yr}$ (Friedlingstein et al., 2019)). About one-half of these emissions, $5 \mathrm{GtC} / \mathrm{yr}$, accumulates in the atmosphere in the form of the greenhouse gas $\mathrm{CO}_{2}$, such that its atmospheric concentration is on the rise. The global mean surface temperature of the Earth is also increasing. These manifestations of climate instability cause concern and are widely discussed across the globe.

As of today, the atmospheric $\mathrm{CO}_{2}$ concentration has grown by one third as compared to its pre-industrial era and got out of equilibrium with the concentration of carbon dioxide dissolved in the ocean. Tending to restore the equilibrium, the ocean consumes about $2 \mathrm{GtC} / \mathrm{yr}$ from the atmosphere in inorganic form. The fate of the remaining 4 $\mathrm{GtC} / \mathrm{yr}$ in the carbon balance (the so-called "missing sink") had long remained enigmatic, even though it might seem natural to immediately assign a role to the biosphere. The global biota synthesizes organic matter at a rate of about $100 \mathrm{GtC} / \mathrm{yr}$ and, in a steady state, decomposes it at an equal rate. This exceeds the rate of anthropogenic carbon emissions by one order of magnitude.

If we accept the concept of the biotic regulation of the environment as the main principle of life organization, then the existence of a biotic sink of atmospheric carbon becomes self-evident. The natural biota should react to an environmental disturbance anthropogenic $\mathrm{CO}_{2}$ emissions - according to the Le Chatelier's principle (Gorshkov, 1995). It should counteract $\mathrm{CO}_{2}$ accumulation and remove the excessive carbon from the atmosphere by transforming it into an inert organic form. To explain the missing sink of 4 $\mathrm{GtC} / \mathrm{yr}$ it is sufficient that global photosynthesis exceeds global decomposition of organic matter by four per cent. Carbon is the main element used by life. Even if $\mathrm{CO}_{2}$ were not a greenhouse gas, the biota should have been compensating for the modern deviation of its atmospheric concentration from the optimal value.

The scientific community has long been reluctant to recognize and admit the existence of a biotic carbon sink. That was due to the prevailing concept that the biota does not regulate concentrations of life-important substances but, instead, is limited by them. As far as the concentrations of nitrogen and phosphorus - the presumed limiting biogens do not change, the ecologists believed that the biosphere productivity could not grow in 
response to the increasing concentration of atmospheric $\mathrm{CO}_{2}$ (Popkin, 2015). Meanwhile the biotic regulation concept predicted that, at constant nitrogen and phosphorus, the stabilizing biotic response should take the form of an excessive synthesis of carbohydrates that do not contain either nitrogen or phosphorus (Gorshkov, 1986).

It was only after many direct measurements proved the increase of plant biomass in different parts of the planets that experts conceded the existence of the stabilizing biotic response to the carbon disturbance ${ }^{1}$. The "missing sink" was mainly assigned to the increasing tree biomass in forest ecosystems (Pan et al., 2011).

However, forest tree biomass cannot grow infinitely (Hubau et al., 2020). The biotic sink will persist if, after the tree death, the wood is not fully decomposed but is partially deposited in soil in the form of long-lived organic substances. Recent studies revealed that the turnover time of organic compounds in soil is mostly determined not by their chemical composition but by functioning of the entire ecological community, plants and soil biota included (Schmidt et al., 2011; Gross, Harrison, 2019; Kuznetsova et al., 2019).

According to the biotic regulation concept, disturbed ecological communities destabilize their environment - this is their principal difference from the ecological communities of natural ecosystems. One example of such a destabilization is the degradation of agricultural soils that contributes appreciably to the global carbon emissions. Unfortunately, soil monitoring predominantly occurs in the developed countries in the agricultural regions. Assessing the dynamics of organic carbon content in the two main reservoirs, soils and the ocean, is significantly more laborconsuming and expensive than measurements

\footnotetext{
1 This effect is now referred to as " $\mathrm{CO}_{2}$-fertilization",
} although, unlike nitrogen or phosphorus, inorganic of tree biomass. There are no long-term programs that would provide a comprehensive assessment of soil carbon in the least-disturbed forests of the world, a significant part of which is located within Russian borders (Smith et al., 2020) - despite the fact that the available regional and global data suggest that the stabilizing response of these ecosystems should be significant (Luyssaert et al., 2008; Kuznetsova et al., 2019; Lukina et al., 2020).

Analyses of chronosequences in natural undisturbed forests reveal that such forests, at constant plant biomass, are able to ensure a soil sink for atmospheric carbon at a rate of about $1 \%$ of primary productivity or about $5 \mathrm{gC} \mathrm{m}^{-2}$ $\mathrm{yr}^{-1}$ in a boreal ecosystem (Wardle et al. 2012). Meanwhile modern increase of atmospheric $\mathrm{CO}_{2}$ appears to enhance the stabilizing response of undisturbed ecosystems by at least one order of magnitude, up to $50 \mathrm{gC} \mathrm{m}^{-2} \mathrm{yr}^{-1}$ and more (Zhou et al., 2006; Kittler et al., 2017). Long-term year-round monitoring is required to quantify this response reliably (Kittler et al., 2017).

Lack of an adequate account of soil carbon dynamics in undisturbed forests and other intact ecosystems results in a potential underestimate of the negative impact on the carbon cycle associated with ecosystem transition from the undisturbed state to a disturbed one, in particular, by a perturbation of the water regime (Kittler et al., 2017; Sheil et al., 2019; Mayer et al., 2020). If the undisturbed Russian forests ensure a soil sink of atmospheric carbon, then turning a given area of undisturbed forest into a disturbed, exploited plot with cultivated trees that have a higher net primary productivity, will lead to an increase in carbon emissions. The stabilizing impact (carbon absorption by the intact forest) will be replaced by a destabilizing one (loss of soil carbon in the disturbed ecosystem) (Dean

carbon has never been used as a fertilizer to enhance plant productivity. 
et al., 2017). A large-scale scientific program studying the potential of soil carbon storage in intact forests will allow one to objectively assess the role of Russian forests in the maintenance of a stable chemical composition of the atmosphere.

\section{Evaporation of moisture by forests: a} critical impact on the temperature regime

Absorption of carbon dioxide by plants occurs during photosynthesis. Stomata of the green leaves open to capture a carbon dioxide molecule from the atmosphere. During this process, water vapor evaporates from the leaves to the atmosphere - more than a hundred water molecules per each absorbed molecule of carbon dioxide. This is transpiration. Evaporation consumes energy the $\mathrm{H}_{2} \mathrm{O}$ molecule has to be extracted from the liquid phase by overcoming the intermolecular forces of attraction. During transpiration, a significant part of the energy of solar radiation is spent to overcome the energy of intermolecular bonds and not on heating the surface. Therefore, all other conditions being equal, the surface temperature of photosynthesizing green leaves and forest canopy is lower than the temperature of a dry surface receiving the same solar flux (Huryna, Pokorný, 2016).

These processes constitute the basis of plant physiology and are well-known (Chapin et al., 2008). However, it was only recently that, based on satellite observations, researchers could evaluate the magnitude of their impact on the continental temperature regime scale (Alkama, Cescatti, 2016). It was found that deforestation leads to an increase of surface temperature during the vegetative season by a few degrees compared to similar areas where the forest cover persists. This local immediate consequence of forest elimination is comparable in magnitude to the modelled global warming due to $\mathrm{CO}_{2}$ doubling in one century.
The importance of these new results consists in revealing the causality between local forestry practices and fire frequency. Temperature increase is one of the main fire hazards (Furyaev et al., 2001). The conventional distinction between fire hazards associated with climate change versus those associated with land use (Molinari et al., 2018) loses its relevance. Researchers of various ecosystems around the world conclude that an increase in the frequency of fires is not an external climatic factor for the forest, but can reflect the history of previous forest cover disturbances, both natural and anthropogenic, including forest logging and fires (Aleinikov, 2019; Sheil, 2020). Making the surface temperature rise due to reduced transpiration, logging and fires increase the likelihood of subsequent fires regardless of the nature of the ignition source. The anthropogenic disturbance of the forest cover may be the root cause of the unprecedented fire regime in Siberia (Feurdean et al., 2020). Moisture deficiency leads to weakening of the remaining trees and exposes them to pests, including invasive species (Hesslerová et al., 2018).

A most important task is to study the ability of undisturbed and little disturbed forests to retain soil moisture. In foreign literature, these issues receive increasing attention (Ilstedt et al., 2016). For boreal forests, it is also known that even relatively late successional stages differ significantly in their ability to stabilize soil moisture (Smirnova et al., 2014).

To ensure effective protection of modern forests, it is necessary on a national scale to study systematically the relationship between the long-term history of anthropogenic impact on ecosystems, their ability to accumulate and preserve soil moisture, and the frequency of fires in them. This will make it possible to minimize anthropogenic disturbances and, consequently, the frequency of fires in the most stable intact forests that are still 
preserved, and use the knowledge about these reference systems to reduce the fire hazard in exploited forest stands.

\section{Continental transport of atmospheric moisture}

Recent studies have revealed a new significant aspect of the forest influence on the climate. The transpiration of the forest cover maintains high humidity in the atmosphere, which determines the intensity of local condensation and precipitation. Condensation of water vapor leads to the formation of pressure gradients that facilitate the transfer of atmospheric moisture from the ocean to land on a continental scale (Makarieva et al., 2014; Poveda et al., 2014). Based on studies of radioactive isotopes in precipitation, it has been shown that the natural forest of the Amazon Basin functions in such a way that the rainy season is two months longer than in treeless regions at the same latitude. Moisture transpiration by the forest cover and moisture condensation over the forest leads to the suction of moist air from the ocean inland (Wright et al., 2017). Similar results were obtained for monsoons in India (Pradhan et al., 2019).

The existence of a forest pump of atmospheric moisture was theoretically predicted by Russian scientists (Makarieva, Gorshkov, 2007; Makarieva et al., 2013). In Russia, such experimental studies have not been carried out - despite the fact that the forest biotic pump is critically important for Russia, which has the largest continental extent in the world. According to the biotic regulation concept, natural forest cover not only compensates for river runoff into the ocean by inflow of moisture through the atmosphere, but also solves the most difficult task of optimizing precipitation in such a way as to minimize extreme fluctuations of the water cycle (droughts and floods). The natural forest performs the biotic control of the water cycle by initiating condensation and precipitation uniformly in space and time. For example, it was found that in some natural rainforests with very high annual rainfall and mountainous terrain the soil erosion and landslides are nevertheless practically absent - because precipitation occurs in the form of regular mild rains (Sillitoe, 1993).

The forest cover of Russia has been changing non-uniformly over the past two hundred years. Patterns of forest exploitation depended on many historical, geographical and socio-economic factors and could differ even within the same administrative region (Aleynikov et al., 2018). In general, in the nineteenth century, exponential population growth led to a decrease in forest area due to the expansion of agricultural land. The industrial revolution has brought additional pressure on forest ecosystems due to the use of wood as a source of energy. The share of forest cover in European Russia and North America in the 19th century sharply decreased, reaching its minimum during the transition of our civilization to fossil fuels (Makarieva, Gorshkov, 2018). In the European part of Russia, this minimum appears to have occurred at the beginning of the twentieth century (Tsvetkov, 1957; Palenova, 2004). The increase in agricultural efficiency, urbanization and the end of the use of wood as the main fuel in the twentieth century somewhat reduced the pressure on forests and resulted in an increase in forest cover in European Russia as compared to the minimum at the beginning of the century. During this period, the Arctic runoff of European rivers also increased (Magritsky et al., 2018). In the stationary case, the river runoff is equal to the influx of atmospheric moisture from the ocean. An increase in river runoff means an increase in the continental transport of atmospheric moisture with an increase in forest cover. 
However, simultaneously with the decrease of the agricultural expansion pressure on the forest, the industrial logging rate had been steadily increasing - starting from the $30 \mathrm{~s}$ and till the end of the 70s of the twentieth century. Thus, from 1929 to 1940 the annual volume of industrial timber in Russia rose by 2.6 times. It declined during the war, but already in 1948 it recovered, reached the maximum of about 350 million cubic metres per year in mid 1970s and only in the 1990s it sharply declined (Zamolodchikov et al. 2015). Since then the forest area has been growing in all East European countries (except Estonia and Latvia) as well as in most regions of Russia (Turubanova et al, 2017). Despite the fact that over the past two hundred years the intensity of anthropogenic pressure on the forest has been varying non-uniformly (both decreasing and increasing), the relative area of undisturbed forests, apparently, has been steadily decreasing, since the increase in forest area occurs due to regrowth of young stands, while the decrease occurs mainly due to the loss of mature forest.

In the view of the large influence of vegetation cover on the temperature of the Earth's surface and all components of the water regime, as well as complex feedbacks between the functioning of ecosystems of varying degrees of disturbance and the state of the water cycle, for correct forecasting of the continental water regime, including river runoff, precipitation, extreme weather events and soil moisture reserves (Groisman et al., 2017; Magritsky et al., 2018; Gu et al., 2019; Chernokulsky et al., 2019, 2020), it is necessary to take into account the regional dynamics of the state of forest ecosystems.

\section{Forest cover reflectivity and cloudiness}

The atmosphere is relatively transparent to solar radiation. A certain share of solar radiation that reaches the Earth's surface is not absorbed but is reflected back to space. The lighter the surface, the higher its reflectivity (albedo). Darker forest cover absorbs more solar radiation than snow cover. Due to the change of albedo, deforestation results in a decrease of temperatures in the cold season. In the growing season the effect of albedo change is overcome by the impact of transpiration. Thus, on clear-cuts, despite their higher albedo, the surface temperature rises in comparison to the undisturbed forest (Mamkin et al., 2019). Thus, deforestation in the boreal zone destabilizes the local temperature regime causing a decrease in temperature in winter and an increase in summer (Alkama, Cescatti, 2016).

About $20 \%$ of solar radiation is reflected back into space by clouds. This cools the Earth - therefore, for example, a cloudy day in summer is cooler than a cloudless one. On the other hand, clouds absorb thermal radiation from the Earth's surface and partially re-emit it back to the surface. This warms the Earth therefore, for example, a cloudy night is warmer than a cloudless one. These opposing influences make cloudiness the main regulator of the planet's temperature regime. Different types of cloud cover predominantly have a warming or cooling effect. So, for example, low clouds predominantly cool the Earth, while high thin clouds predominantly warm it. Evaporation from the surface of the forest cover maintains the high moisture content of the atmosphere required for cloud formation. Biotic control of cloudiness using the two levers (cooling and warming) allows the forest to stabilize the temperature regime (Gorshkov and Makarieva, 2006).

The latest generation of global climate models predict significantly more warming per $\mathrm{CO}_{2}$ doubling, more than four and a half degrees Celsius instead of three, up to almost six degrees in some models (Zelinka et al., 2020). For some models, the increase compared to the previous generation is about 
two degrees, which is comparable in magnitude with the total global warming estimated by the Russian global climate model of the Institute of Computational Mathematics of the Russian Academy of Sciences (Zelinka et al., 2020). This change is associated with a more detailed account of the dependence of cloudiness, especially at high latitudes, on temperature. These dependencies are formulated on the basis of observations. The disappearance of intact forests, documented over the past two decades (Heino et al., 2015; Potapov et al., 2017), could have led to such changes in the characteristics of precipitation and cloudiness that, according to the latest studies, can have serious global consequences.

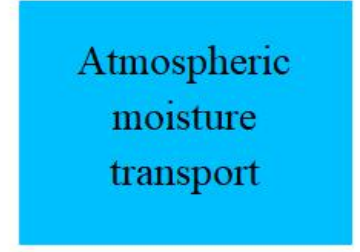

Transpiration
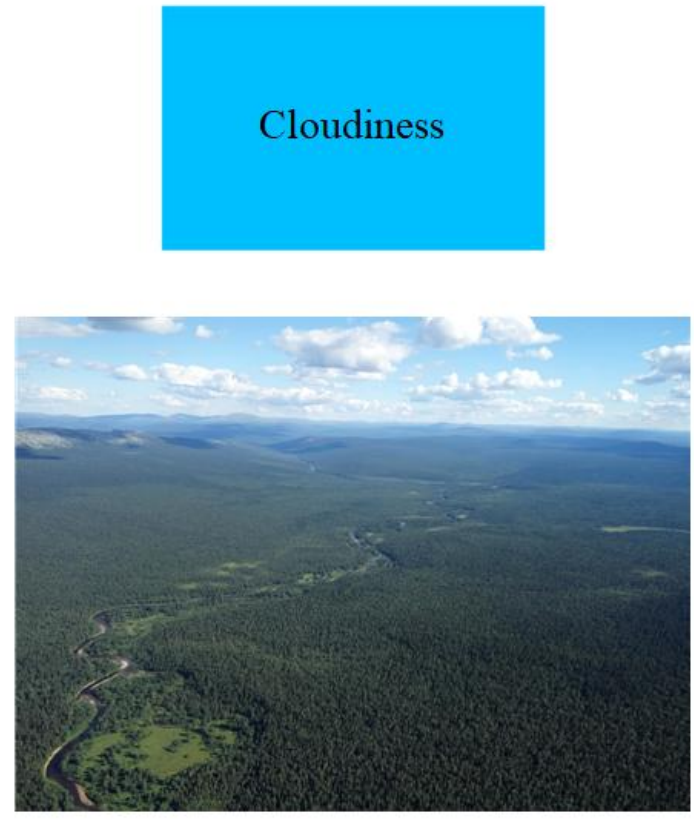

Reflection

of solar

radiation

Absorption

of atmospheric

carbon

Fig. 1. Some aspects of how forests influence climate. Traditional consideration has focused on the sequestration of carbon in tree biomass with information about soil dynamics largely absent; more recently, forest albedo began to be considered (Andrews et al., 2017; Anderegg et al., 2020). The aspects related to the water cycle (blue rectangles) are least studied although they, according to the recent data, play a crucial role in climate stability (Sheil et al., 2019; Zelinka et al., 2020).

\section{Climate-regulating forests - least- disturbed forests}

It is necessary to emphasize the principle difference between such notions as the regulation (stabilization) of climate and environment, on the one hand, and an influence on them, on the other, which can be either stabilizing or destabilizing. The regulation consists in providing a stabilizing response aimed at compensating the disturbances and returning the environment and climate to the state optimal for life. For example, if the temperature rises, to stabilize the temperature regime an intact forest cover can facilitate formation of the low clouds that cool. If the temperature declines, it can facilitate formation of higher cloudiness with a warming effect. Such a regulation is a most complex process that relies on inter-species interactions that took millions of years to evolve. Modern research demonstrates that the production of aerosols, which serve as condensation nuclei 
during cloud formation, involves not just trees, but the entire ecological community, including microorganisms (Pöschl et al, 2010; Sheil, 2018).

A forest disturbed by fires and cutting spends its power on self-recovery, therefore its potential for regulation of the external environment is lowered, and such a forest can destabilize the environment. As long as the area of disturbed forest remains small, this does not significantly affect the sustainability of the regional climate provided by the remaining undisturbed natural forest. However, with an increase in disturbed areas and a decrease in the share of natural forests, climate destabilization will also increase. In this context, the long-term tendency towards a decrease in low cloudiness in Russia is noteworthy (Khlebnikova, Sall, 2009).

Impacts of forest on climate involve a variety of physical, biochemical and ecological processes with complex feedbacks (Fig. 1). In all of them, the biotic regulation of moisture is a key factor (Sheil et al., 2019). Indeed, the formation of cloud cover is closely related to the atmospheric transport of moisture, which, in turn, depends on the evaporation of moisture by the forest (Wright et al., 2017; Pradhan et al., 2019). Efficient accumulation of carbon in an ecosystem is impossible when there is a deficiency of soil moisture, which determines the rate of photosynthesis (Kittler et al., 2017).

With the development of computer technologies, the phenomenological model approach began to prevail in environmental science at the expense of the conceptual theoretical approach (Emanuel, 2020). The collected empirical data are statistically processed and the revealed formal correlations are used as the basis for the modeled relationships. This does not guarantee a scientific understanding of the processes that determine the established correlations and their dynamics. The inadequacy and inefficiency of such an approach to the study of the most complex problems of climatology is gradually being recognized and noted by leading scientists (Belotelov, 2020; Emanuel, 2020).

The concept of the biotic regulation of the environment provides the necessary interdisciplinary theoretical framework for studying the impact of ecosystems on climate. The environment in which life in general, and forest ecosystems in particular, exist, is in a non-equilibrium physico-chemical state. In the absence of biotic control, the environment disintegrates (decays) into a state unfavorable for life on a short time scale of the order of several years. Natural biota, using solar radiation, prevents the spontaneous decay of a favorable environment and increases its lifetime to geological scales (Makarieva et al., 2020).

From the biotic regulation viewpoint, the most important dynamic parameter that distinguishes ecosystems is the degree of their disturbance, which determines the ability of the ecosystem to restore itself to its stationary stable state. Biological species persist virtually unchanged for millions of years, and ecosystems persist for tens of millions of years. This means that natural ecosystems are capable of recovering from disturbances. Natural forest ecosystems display maximum resistance to abiotic (fires, windfalls) and biotic (insect invasions) disturbances. In these ecosystems all species have stable population densities from generation to generation (gap dynamics).

After a heavy disturbance of the ecosystem that goes beyond its resilience threshold, the ecosystem cannot spontaneously restore to its stable state. An irreversible loss of the gene pool occurs until the forest completely disappears (Kukavskaya et al., 2016). It is necessary to distinguish between ecosystems that are on a trajectory towards degradation, from those that are capable of self-recovery to 
an initial stable state where all key species are present. Degrading ecosystems obviously cannot regulate the climate.

In even-aged tree stands that form after a large-scale fire or cutting, all trees reach mature and then age almost simultaneously. If no protection measures are taken, such tree stands die off, and the resulting large stock of dead wood will increase the likelihood of fires and pest attacks (Hesslerová et al., 2018). When a large number of trees fall simultaneously, temperature rises and humidity diminishes, which increases fire hazards even further. Such tree stands that have experienced a disturbance beyond their self-recovery threshold and would take too long to self-restore, do indeed require an anthropogenic interference.

In contrast, natural ecosystems are stable in the absence of anthropogenic impact. In a natural undisturbed ecosystem with a developed gap dynamic, trees of all species and all ages are simultaneously present, including the maximum age for each species. The age composition of tree populations does not change over time (it can be compared with the age distribution in a healthy human population, where children, adults and elderly people are present at any time). The death of individual old trees or tree clumps in the natural ecosystem is local and does not lead to increased aridity, so the fire hazard remains low.

It is important to note that there is no established term for natural forests in forestry practice. Sometimes the terms "old-growth" or "overripe" are used. These terms are misleading, because despite the fact that old trees are always present in such an ecosystem, to call it "overripe" or "old-growth", i.e. requiring an anthropogenic intervention, is not legitimate. Such an ecosystem is practically immortal, like life itself. It is a stable ecosystem that has complete genetic information about the processes in the environment it regulates.

In modern studies, the impact of biota on climate is described by a number of integral simplified parameters, such as albedo, carbon content, primary productivity, surface roughness, etc. However, with the same model parameters, the responses to environmental changes are fundamentally different in a degrading ecosystem and in an ecosystem that has not lost the ability to heal itself and retains the entirety of genetic information about the regulation of the environment and climate. This fundamental difference is not taken into account in climate research today (Groisman et al., 2017). At the same time, various researchers independently come to the understanding that intact resilient ecosystems are distinguished by their importance for the environment and climate (Watson et al., 2018; Funk et al., 2019; Jonsson et al., 2020; Braslavskaya et al., 2020). The concept of biotic regulation provides this understanding with a theoretical basis.

Taking into account the long-term presence of humans on the territory of modern Russia and the anthropogenic perturbations of ecosystems, clarification of the definition of a natural "reference" ecosystem - that is, the most stable ecosystem with the maximum climate-regulating potential - for each region is a serious interdisciplinary scientific problem. For example, what should be the degree of forest canopy closure in the reference ecosystem in order to provide the necessary values of surface roughness, albedo, transpiration fluxes and moisture accumulation in the soil, which are optimal for maintaining a stable temperature regime and moisture cycle? This question is directly related to the question of the role of large animals in the ecosystem and ecological restrictions on their population density (Gorshkov, Makarieva, 2020; Nefiodov, 2020; Hatton, Galbraith, 2020; 
Sheil, 2020; Geraskina et al., 2020; Makarieva et al., 2020).

One of the key issues is the minimum sufficient size of the Earth's surface area that has to be covered by natural ecosystems such that they could stabilize the environment and climate. However, it is clear from the already available information that forest ecosystems preserved on little disturbed territories are critically important for climate stabilization. Namely these ecosystems should become the core of the new legislative category of climateregulating forests. Resilient natural forests that do not fit the modern formal definition of the intact forest landscapes, in particular, due to their insufficient size (less than 50 thousand hectares), should be protected as potential "growth points" for their subsequent expansion to a larger area. In the central and southern regions of Russia, such small areas are often the only remaining etalons of sustainable ecosystems, and therefore they are of special importance.

\section{Russian forest policy and the international climate agenda}

The on-going global and regional climatic changes threaten the existence and development of both particular countries and our civilization as a whole. In the face of this threat, the humanity is attempting coordinated efforts that increasingly determine the international political agenda. At the same time, the awareness and recognition by many people of the real climate threat creates the possibility of unfair political speculations that would reflect the competition of various economic groups rather than the fight against climate change. In this situation, the importance of objective scientific knowledge as an "arbiter" in political and geo-economic disputes increases.

In the field of climate change, the protection of the national interests of the Russian Federation directly depends on an objective scientific assessment of the ecological contribution that ecosystems located on the territory of our country make to the stabilization of the global and regional climate. It must be emphasized that scientific ideas in this area are changing rapidly today. Along with them, although with a delay of several years, the official recommendations to politicians from reputable international scientific organizations, including the IPCC, are also changing. In current global climate agenda one can discern the contours of an emerging conceptual turn from carbon to water. While carbon storage by forest ecosystems is still seen as a major aspect of the forest impact on climate, there are justified calls to explore this issue more comprehensively in a hydrological and ecological context (e.g. Sheil et al., 2019; Anderegg et al., 2020). The change in agenda will lead to the fact that the rules for accounting for the influence of various countries on the climate will change, and Russian interests will be affected in the first place. Proactive actions are required to protect them.

One-fifth of the world's forest ecosystems are located in Russia. Until recently, the main influence of the forest on climate was considered to be emission (during cutting and fires) or absorption (during forest restoration) of carbon dioxide. The absorption of excess atmospheric carbon by Russian forests largely compensates for the carbon emissions associated with the extraction of oil, gas, and coal by Russian companies (Romanovskaya, Federichi, 2015). However, today, according to the latest IPCC report (IPCC, 2019), for forests of high latitudes, including Russian ones, their influence on the reflectivity of the planet is increasingly emphasized (Andrews et al., 2017; Winckler et al., 2019a, b). The argument is put forward that the heating of the planet's surface due to the absorption of solar 
radiation by the forest cover in winter can exceed the cooling due to the absorption of excess carbon dioxide by the forest. If this type of calculations is, despite their high uncertainties up to the sign change, included into official schemes for assessing the climatic impacts of different countries, - and such attempts are already under way (see, e.g., Duveiller et al., 2020), - then Russian carbon footprint and the corresponding economic sanctions will rise substantially. Russia will officially lose its climate buffer.

The possibility of such a negative scenario derives from the fact that, for the first, natural intact forests of Russia have been studied significantly less intensely than the tropical forests of Brazil or Indonesia. For the second, Russian undisturbed forests are unique. Forests that have an age of the last disturbance exceeding several hundred years do not have analogues in the world; they are preserved in the oldest nature reserves or in hard-to-reach locations. The climatic impact of Russian forests is therefore estimated on the basis of global and regional models/parameterizations, which, as IPCC experts themselves recognize, are characterized by large uncertainties.

It is not possible to convincingly demonstrate the significant contribution of Russian forests into stabilization of the global and regional climate without up-to-date fundamental scientific knowledge about the climate-regulating function of natural Russian forests. It is necessary to unite efforts of scientists from different disciplines, to systematize the available data in the framework of the biotic regulation concept, to perform pilot research of the most important climatic characteristics of undisturbed forests and use the obtained results to suggest a new international climate narrative. As long as its intact forests are preserved, Russia remains a global and regional ecological donor that contributes to the maintenance of climate stability. With a pro-active attitude, Russia can become a global ecological leader in the new narrative having united countries that preserve large-scale natural forest territories.

\section{Conclusion}

Fundamental science discovers the laws of nature that form the basis for a consistent objective picture of the world. Violation of these laws is not possible in the sense that such a violation would be incompatible with life. All laws of human society that regulate economic, political, social and cultural relations are secondary; their formulations should properly take into account the functioning principles of the biosphere and the place of man within it.

Under conditions of a looming threat of an irreversible global climate change, the biotic regulation concept assigns the central role to natural ecosystems in the environmental regulation and imposes fundamental restrictions on what modern people should do. Only natural biota can keep the environment in a stable state favorable for life, and it spends almost all its power for this task. Anthropogenic exploitation, including timber harvesting, destroys the ability of ecosystems to regulate environment and climate.

The sought-for balance between different ecosystem functions (including the balance between production of timber and other wood products on the one hand and climate regulation by natural forest ecosystems on the other) can only be achieved through spatial delineation of these functions (balance through delineation).

Forest ecosystems need to be classified according to the degree of their disturbance. Forest industry in commercial forests should proceed intensively and be limited to those areas that have been already affected by exploitation. The least-disturbed forest ecosystems, where the anthropogenic disturbance has not gone above the threshold 
and which therefore remain capable of selfrecovery to a stable state, should be completely withdrawn from economic activities and allocated into a separate category with the maximum degree of legal protection (in particular, in the framework of the Forest Code

\section{REFERENCES}

Aleinikov A.A., The fire history in pine forests of the plain area in the Pechora-Ilych Nature Biosphere Reserve (Russia) before 1942: possible anthropogenic causes and longterm effects, Nature Conservation Research, 2019, Vol. 4, Suppl. 1, pp. 21-34. URL: https://doi.org/10.24189/ncr.2019.033

Aleynikov A.A., Stenno S.P., Tsiberkin N.G., Melnichuk A.F., Sadovnikova E.N., Vlijanie permskih soljanyh promyslov XVXIX vv. na transformaciju lesov: opyt ocenki masshtabov vozdejstvija (Influence of the Perm salt production in the XV-XIX century for forest transformation: Impact assessment), Russian Journal of Ecosystem Ecology, 2018, Vol. 3, Iss. 1. URL: https://doi.org/10.21685/2500-0578-2018$\underline{1-2}$

Alkama R., Cescatti A., Biophysical climate impacts of recent changes in global forest cover, Science, 2016, Vol. 351, Iss. 6273, pp. 600-604.

URL: https://doi.org/10.1126/science.aac8083

Anderegg W.R.L., Trugman A.T., Badgley G., Anderson C.M., Bartuska A., Ciais P., Cullenward D., Field C.B., Freeman J., Goetz S. J., Hicke J.A., Huntzinger D., Jackson R.B., Nickerson J., Pacala S., Randerson J.T., Climate-driven risks to the climate mitigation potential of forests, Science, 2020, Vol. 368, Iss. 6497, p. eaaz7005.

URL: https://doi.org/10.1126/science.aaz7005

Andrews T., Betts R.A., Booth B.B.B., Jones C.D., Jones G.S., Effective radiative forcing from historical land use change, Climate Dynamics, 2017, Vol. 48, pp. 3489-3505. of Russian Federation), including a ban on their transfer to the category of commercial forests and other land categories, and be the subject of broad interdisciplinary scientific research.

URL: https://doi.org/10.1007/s00382-0163280-7

Belotelov N.V., Impact of the works of V.G. Gorshkov on the development of mathematical models of ecosystems, Russian Journal of Ecosystem Ecology, 2020, Vol. 5, Iss. 2.

URL: https://doi.org/10.21685/2500-05782020-2-7

Braslavskaya T.Yu., Kolbowsky E.Yu., Esipova E.S., Korotkov V.N., Nemchinova A.V., Churakova E.Yu., Kozykin A.V., Kulyasova A.A., Aleinikov A.A., Ladshaftno-bassejnovyj podhod V jekologicheskoj ocenke malonarushennyh lesov Onezhskogo poluostrova (The Landscape-Basin Approach for Ecological Evaluation of Intact Forest Areas on the Onega Peninsula (Russia)), Bulletin of the Russian Academy of Sciences. Geographical series, 2020, Vol. 84, No. 6, pp.1-15.

Chapin F.S., Randerson J.T., McGuire A.D., Foley J.A., Field C.B., Changing feedbacks in the climate-biosphere system, Frontiers in Ecology and the Environment, 2008, Vol. 6, Iss. 6, pp. 313-320. URL: https://doi.org/10.1890/080005

Chernokulsky A., Kozlov F., Zolina O., Bulygina O., Mokhov I.I., Semenov V.A., Observed changes in convective and stratiform precipitation in Northern Eurasia over the last five decades, Environmental Research Letters, 2019, Vol. 14, Iss. 4, p. 045001 .

URL: $\quad$ https://doi.org/10.1088/17489326/aafb82 
Chernokulsky A., Kurgansky M., Mokhov I., Shikhov A., Azhigov I., Selezneva E., Zakharchenko D., Antonescu B., Kühne T., Tornadoes in Northern Eurasia: From the Middle Age to the Information Era, Monthly Weather Review, 2020, Vol. 148, Iss. 8 , pp. 3081-3110. URL: https://doi.org/10.1175/MWR-D-19$\underline{0251.1}$

Dean C., Kirkpatrick J.B., Friedland A.J., Conventional intensive logging promotes loss of organic carbon from the mineral soil, Global Change Biology, 2017, Vol. 23, Iss. 1, pp. 1-11.

URL: https://doi.org/10.1111/gcb.13387

Duveiller G., Caporaso L., Abad-Viñas R., Perugini L., Grassi G., Arneth A., Cescatti A., Local biophysical effects of land use and land cover change: towards an assessment tool for policy makers, Land Use Policy, 2020, Vol. 91, p. 104382. URL: https://doi.org/10.1016/j.landusepol.2019.1 $\underline{04382}$

Emanuel K., The Relevance of Theory for Contemporary Research in Atmospheres, Oceans and Climate, American Geophysical Union Advances, 2020, Vol. 1, Iss. 2, p. e2019AV000129. URL: https://doi.org/10.1029/2019AV000129

Feurdean A., Florescu G., Tanţău I., Vannière B., Diaconu A.-C., Pfeiffer M., Warren D., Hutchinson S.M., Gorina N., Gałka M., Kirpotin S., Recent fire regime in the southern boreal forests of western Siberia is unprecedented in the last five millennia, Quaternary Science Reviews, 2020, Vol. 244, p. $106495 . \quad$ URL: https://doi.org/10.1016/j.quascirev.2020.10 $\underline{6495}$

Friedlingstein P., Jones M.W., O'Sullivan M., Andrew R.M., Hauck J., Peters G.P., Peters W., Pongratz J., Sitch S., Le Quéré C., Bakker D.C.E., Canadell J.G., Ciais P., Jackson R.B., Anthoni P., Barbero L.,
Bastos A., Bastrikov V., Becker M., Bopp L., Buitenhuis E., Chandra N., Chevallier F., Chini L.P., Currie K.I., Feely R.A., Gehlen M., Gilfillan D., Gkritzalis T., Goll D.S., Gruber N., Gutekunst S., Harris I., Haverd V., Houghton R.A., Hurtt G., Ilyina T., Jain A.K., Joetzjer E., Kaplan J.O., Kato E., Goldewijk K.K., Korsbakken J.I., Landschützer P., Lauvset S.K., Lefèvre N., Lenton A., Lienert S., Lombardozzi D., Marland G., McGuire P.C., Melton J.R., Metzl N., Munro D.R., Nabel J.E.M.S., Nakaoka S.-I., Neill C., Omar A.M., Ono T., Peregon A., Pierrot D., Poulter B., Rehder G., Resplandy L., Robertson E., Rödenbeck C., Séférian R., Schwinger J., Smith N., Tans P.P., Tian H., Tilbrook B., Tubiello F.N., van der Werf G.R., Wiltshire A.J., Zaehle S., Global Carbon Budget 2019, Earth System Science Data, 2019, Vol. 11, Iss. 4, pp. 1783-1838. URL: https://doi.org/10.5194/essd-11-1783-2019

Funk J.M., Aguilar-Amuchastegui N., Baldwin-Cantello W., Busch J., Chuvasov E., Evans T., Griffin B., Harris N., Ferreira M.N., Petersen K., Phillips O., Soares M.G., van der Hoff R.J.A., Securing the climate benefits of stable forests, Climate Policy, 2019, Vol. 19, Iss. 7, pp. 845-860, URL:https://doi.org/10.1080/14693062.2019.1 598838

Furyaev V.V., Vaganov E.A., Tchebakova N.M., Valendik E.N., Effects of fire and climate on successions and structural changes in the Siberian boreal forest, Eurasian Journal of Forest Research, 2001, Vol. 2, pp. 1-15. URL: http://hdl.handle.net/2115/22125

Gagarin $\mathrm{Yu}$. N., Koncepcija proekta federal'nogo zakona «Lesnoi kodeks Rossiiskoi Federacii» (Concept draft bill of the Federal law «Forest Code of the Russian Federation»), Forest Science Issues, 2020, Vol. 3, No 3, pp. 1-45. URL: 
$\underline{\text { http://jfsi.ru/en/concept of the forest cod }}$ e rf/

Geraskina A.P., Smirnova O.V., Korotkov V.N., Kudrevatykh I.Yu., Productivity and content of macro- and microelements in the phytomass of ground vegetation of typical and unique taiga forests of the Northern Urals (example of spruce-fir forests of the Pechora-Ilych nature reserve), Russian Journal of Ecosystem Ecology, 2020, Vol. 5. Iss. 2. URL: https://doi.org/10.21685/25000578-2020-2-1

Gorshkov V.G., Atmospheric disturbance of the carbon cycle: Impact upon the biosphere, IL Nuovo Cimento C, 1986, Vol. 9, Iss. 5, pp. 937-952. URL: https://doi.org/10.1007/BF02891905

Gorshkov V.G., Makarieva A.M., Key ecological parameters of immotile versus locomotive life, Russian Journal of Ecosystem Ecology, 2020, Vol. 5, Iss. 1.

URL: https://doi.org/10.21685/2500-05782020-1-1

Gorshkov V.G., Makarieva A.M., Priroda nabljudaemoj ustojchivosti klimata Zemli (The nature of the observed climate stability on Earth), Geoekologiya, 2006, No. 3, pp. 483-495.

Gorshkov V.G., Physical and Biological Bases of Life Stability. Man. Biota. Environment. Berlin: Springer, 1995, 340 p. DOI: 10.1007/978-3-642-85001-1

Groisman P., Shugart H., Kicklighter D., Henebry G., Tchebakova N., Maksyutov S., Monier E., Gutman G., Gulev S., Qi J., Prishchepov A., Kukavskaya E., Porfiriev B., Shiklomanov A., Loboda T., Shiklomanov N., Nghiem S., Bergen K., Albrechtová J., Chen J., Shahgedanova M., Shvidenko A., Speranskaya N., Soja A., de Beurs K., Bulygina O., McCarty J., Zhuang Q., Zolina O., Northern Eurasia Future Initiative (NEFI): facing the challenges and pathways of global change in the twenty- first century, Progress in Earth and Planetary Science, 2017, Vol. 4, p. 41. URL: https://doi.org/10.1186/s40645-017$\underline{0154-5}$

Gross C.D., Harrison R.B., The case for digging deeper: Soil organic carbon storage, dynamics, and controls in our changing world, Soil Systems, 2019, Vol. 3, Iss. 2, p. 28.

URL:https://doi.org/10.3390/soilsystems3020 $\underline{028}$

Gu X., Zhang Q., Li J., Singh V. P., Liu J., Sun P., $\mathrm{He}$ C., $\mathrm{Wu}$ J., Intensification and expansion of soil moisture drying in warm season over Eurasia under global warming, Journal of Geophysical Research: Atmospheres, 2019. Vol. 124, Iss. 7, pp. 3765-3782.

URL: https://doi.org/10.1029/2018JD029776

Hatton I., Galbraith E., Commentary on "Key ecological parameters of immotile versus locomotive life" by V.G. Gorshkov and A.M. Makarieva, Russian Journal of Ecosystem Ecology, 2020, Vol. 5, Iss. 2. URL: https://doi.org/10.21685/2500-05782020-2-5

Heino M., Kummu M., Makkonen M., Mulligan M., Verburg P.H., Jalava M., Räsänen T.A., Forest Loss in Protected Areas and Intact Forest Landscapes: A Global Analysis, Public Library of Science One, 2015, Vol. 10, Iss. 10, p. e0138918. URL:https://doi.org/10.1371/journal.pone. $\underline{0138918}$

Hesslerová P., Huryna H., Pokorný J., Procházka J., The effect of forest disturbance on landscape temperature, Ecological Engineering, 2018, Vol. 120, pp. 345-354. URL: https://doi.org/10.1016/j.ecoleng.2018.06.011

Hubau W., Lewis S.L., Phillips O.L., AffumBaffoe K., Beeckman H., Cuní-Sanchez A., Daniels A. K., Ewango C.E.N., Fauset S., Mukinzi J. M., Sheil D., Sonké B., Sullivan 
M.J.P., Sunderland T.C.H., Taedoumg H., Thomas S.C., White L.J.T., Abernethy K.A., Adu-Bredu S., Amani C.A., Baker T.R., Banin L.F., Baya F., Begne S.K., Bennett A.C., Benedet F., Bitariho R., Bocko Y.E., Boeckx P., Boundja P., Brienen R.J.W., Brncic T., Chezeaux E., Chuyong G.B., Clark C. J., Collins M., Comiskey J.A., Coomes D.A., Dargie G.C., de Haulleville T., Kamdem M.N.D., Doucet J.-L., Esquivel-Muelbert A., Feldpausch T.R., Fofanah A., Foli E.G., Gilpin M., Gloor E., Gonmadje C., Gourlet-Fleury S., Hall J.S., Hamilton A.C., Harris D.J., Hart T.B., Hockemba M.B.N., Hladik A., Ifo S.A., Jeffery K.J., Jucker T., Yakusu E.K., Kearsley E., Kenfack D., Koch A., Leal M.E., Levesley A., Lindsell J.A., Lisingo J., Lopez-Gonzalez G., Lovett J.C., Makana J.R., Malhi Y., Marshall A.R., Martin J., Martin E.H., Mbayu F.M., Medjibe V.P., Mihindou V., Mitchard E.T.A., Moore S., Munishi P.K.T., Bengone N.N., Ojo L., Ondo F.E., Peh K.S.-H., Pickavance G.C., Poulsen A.D., Poulsen J.R., Qie L., Reitsma J., Rovero F., Swaine M.D., Talbot J., Taplin J., Taylor D.M., Thomas D.W., Toirambe B., Mukendi J.T., Tuagben D., Umunay P.M., van der Heijden G.M.F., Verbeeck H., Vleminckx J., Willcock S., Wöll H., Woods J.T., Zemagho L., Asynchronous carbon sink saturation in African and Amazonian tropical forests, Nature, 2020, Vol. 579, pp. 80-87. URL: https://doi.org/10.1038/s41586-020-2035-0 Huryna H., Pokorný J., The role of water and vegetation in the distribution of solar energy and local climate: a review, Folia Geobotanica, 2016, Vol. 51, pp. 191-208.

URL: https://doi.org/10.1007/s12224-016$\underline{\text { 9261-0 }}$

Ilstedt U., Bargués Tobella A., Bazié H.R., Bayala J., Verbeeten E., Nyberg G., Sanou J., Benegas L., Murdiyarso D., Laudon H.,
Sheil D., Malmer A., Intermediate tree cover can maximize groundwater recharge in the seasonally dry tropics, Scientific Reports, 2016, Vol. 6, p. 21930. URL: https://doi.org/10.1038/srep21930

IPCC, 2019: Jia G., Shevliakova E., Artaxo P., De Noblet-Ducoudré N., Houghton R., House J., Kitajima K., Lennard C., Popp A., Sirin A., Sukumar R., Verchot L., Chapter 2. Land-climate interactions, In: Climate Change and Land: an IPCC special report on climate change, desertification, land degradation, sustainable land management, food security, and greenhouse gas fluxes in terrestrial ecosystems [Shukla P.R., Skea J., Calvo Buendia E., Masson-Delmotte V., Pörtner H.-O., Roberts D.C., Zhai P., Slade R., Connors S., van Diemen R., Ferrat M., Haughey E., Luz S., Neogi S., Pathak M., Petzold J., Portugal Pereira J., Vyas P., Huntley E., Kissick K., Belkacemi M., Malley J. (eds.)]. 2019. In press. URL: https://www.ipcc.ch/srccl/cite-report/

Jonsson M., Bengtsson J., Moen J., Gamfeldt L., Snäll T., Stand age and climate influence forest ecosystem service delivery and multifunctionality, Environmental Research Letters, 2020, Vol. 15, Iss. 9, p. 0940a8. URL: https://doi.org/10.1088/17489326/abaflc

Khlebnikova E.I., Sall I.A., Peculiarities of climatic changes in cloud cover over the Russian Federation, Russian Meteorology and Hydrology, 2009, Vol. 34, pp. 411-417. URL:https://doi.org/10.3103/S106837390907 $\underline{0012}$

Kittler F., Heimann M., Kolle O., Zimov N., Zimov S., Göckede M., Long-term drainage reduces $\mathrm{CO}_{2}$ uptake and $\mathrm{CH}_{4}$ emissions in a Siberian permafrost ecosystem, Global Biogeochemical Cycles, 2017, Vol. 31, Iss. 12, pp. 1704-1717. URL: https://doi.org/10.1002/2017GB005774 
Kukavskaya E.A., Buryak L.V., Shvetsov E.G., Conard S.G., Kalenskaya O.P., The impact of increasing fire frequency on forest transformations in southern Siberia, Forest Ecology and Management, 2016, Vol. 382, pp. 225-235. URL: https://doi.org/10.1016/j.foreco.2016.10.015

Kuznetsova A.I., Lukina N.V., Tikhonova E.V., Gornov A.V., Gornova M.V., Smirnov V.E., Geraskina A.P., Shevchenko N.E., Tebenkova D.N., Chumachenko S.I., Carbon stock in sandy and loamy soils of coniferous-broadleaved forests at different succession stages, Eurasian Soil Science, 2019, Vol. 52, Iss. 7, pp. 756-768. URL: https://doi.org/10.1134/S1064229319070081

Lukina N., Kuznetsova A., Tikhonova E., Smirnov V., Danilova M., Gornov A., Bakhmet O., Kryshen A., Tebenkova D., Shashkov M., Knyazeva S., Linking forest vegetation and soil carbon stock in Northwestern Russia, Forests, 2020, Vol. 11, Iss. 9, p. 979.

URL: https://doi.org/10.3390/f11090979

Luyssaert S., Schulze E.-D., Börner A., Knohl A., Hessenmöller D., Law B.E., Ciais P., Grace J., Old-growth forests as global carbon sinks, Nature, 2008, Vol. 455, pp. 213-215.

URL: https://doi.org/10.1038/nature07276

Magritsky D.V., Frolova N.L., Evstigneev V.M., Povalishnikova E.S., Kireeva M.B., Pakhomova O.M., Long-term Changes of River Water Inflow into the Seas of the Russian Arctic Sector, Polarforschung, 2018, Vol. 87, Iss. 2, pp. 177-194. URL: https://doi.org/10.2312/polarforschung. 87. 2.177

Makarieva A.M., Gorshkov V.G., "Okruzhajushhaja prirodnaja sreda poterjala ustojchivost' i stremitel'no razrushaetsja..." ("The natural environment has lost stability and is rapidly degrading..."), Energy: Economics,
Technology, Ecology, 2018, No. 5, pp. 2341.

Makarieva A.M., Gorshkov V.G., Biotic pump of atmospheric moisture as driver of the hydrological cycle on land, Hydrology and Earth System Sciences, 2007, Vol. 11, pp. 1013-1033.

URL: $\quad$ https://doi.org/10.5194/hess-11$\underline{1013-2007}$

Makarieva A.M., Gorshkov V.G., Li B.-L., Revisiting forest impact on atmospheric water vapor transport and precipitation, Theoretical and Applied Climatology, 2013, Vol. 111, pp. 79-96. URL: https://doi.org/10.1007/s00704-012-0643-9

Makarieva A.M., Gorshkov V.G., Sheil D., Nobre A.D., Bunyard P., Li B.-L., Why does air passage over forest yield more rain? Examining the coupling between rainfall, pressure, and atmospheric moisture content, Journal of Hydrometeorology, 2014, Vol. 15, Iss. 1, pp. 411-426.

URL: https://doi.org/10.1175/JHM-D-12$\underline{0190.1}$

Makarieva A.M., Nefiodov A.V., Li B.-L., Life's Energy and Information: Contrasting Evolution of Volume- versus SurfaceSpecific Rates of Energy Consumption, Entropy, 2020, Vol. 22, Iss. 9, p. 1025. URL: https://doi.org/10.3390/e22091025

Mamkin V., Kurbatova J., Avilov V., Ivanov D., Kuricheva O., Varlagin A., Yaseneva I., Olchev A., Energy and $\mathrm{CO}_{2}$ exchange in an undisturbed spruce forest and clear-cut in the Southern Taiga, Agricultural and Forest Meteorology, 2019, Vol. 265, pp. 252-268. URL:https://doi.org/10.1016/j.agrformet.2018. $\underline{11.018}$

Mayer M., Prescott C.E., Abaker W.E.A., Augusto L., Cécillon L., Ferreira G.W.D., James J., Jandl R., Katzensteiner K., Laclau J.-P., Laganière J., Nouvellon Y., Paré D., Stanturf J.A., Vanguelova E.I., Vesterdal L., Tamm Review: Influence of forest 
management activities on soil organic carbon stocks: A knowledge synthesis, Forest Ecology and Management, 2020, Vol. 466, p. 118-127. URL: https://doi.org/10.1016/j.foreco.2020.118127

Molinari C., Lehsten V., Blarquez O., Carcaillet C., Davis B.A.S., Kaplan J.O., Clear J., Bradshaw R.H.W., The climate, the fuel and the land use: Long-term regional variability of biomass burning in boreal forests, Global Change Biology, 2018, Vol. 24, Iss. 10, pp. 4929-4945.

URL: https://doi.org/10.1111/gcb.14380

Nefiodov A.V., Universal patterns of matter and energy fluxes in land and ocean ecosystems, Russian Journal of Ecosystem Ecology, 2020, Vol. 5, Iss. 2. URL: https://doi.org/10.21685/2500-0578-2020-2-6

Palenova M.M., Obshhaja harakteristika vidovogo i vozrastnogo sostava drevostoev sovremennyh lesov, Vostochnoevropejskie lesa: istorija $\mathrm{v}$ golocene i sovremennost' (General characteristics of the species and age composition of stands of modern forests, East European forests: History in the Holocene and the present), Smirnova O.V. (red.). Book 1. Moscow: Nauka, 2004, pp. 314-324.

URL:https://istina.msu.ru/publications/boo $\mathrm{k} / 7873263 /$

Pan Y., Birdsey R.A., Fang J., Houghton R., Kauppi P.E., Kurz W.A., Phillips O.L., Shvidenko A., Lewis S.L., Canadell J. G., Ciais P., Jackson R.B., Pacala S.W., McGuire A.D., Piao S., Rautiainen A., Sitch S., Hayes D., A large and persistent carbon sink in the world's forests, Science, 2011, Vol. 333, Iss. 6045, pp. 988-993. URL: https://doi.org/10.1126/science.1201609

Popkin G., Weighing the world's trees, Nature, 2015, Vol. 523, Iss. 7558, pp. 20-22.

URL: https://doi.org/10.1038/523020a

Pöschl U., Martin S.T., Sinha B., Chen Q., Gunthe S.S., Huffman J.A., Borrmann S.,
Farmer D.K., Garland R.M., Helas G., Jimenez J.L., King S.M., Manzi A., Mikhailov E., Pauliquevis T., Petters M.D., Prenni A.J., Roldin P., Rose D., Schneider J., Su H., Zorn S.R., Artaxo P., Andreae M.O., Rainforest Aerosols as Biogenic Nuclei of Clouds and Precipitation in the Amazon, Science, 2010, Vol. 329, Iss. 5998, pp. 1513-1516. URL: https://doi.org/10.1126/science.1191056

Potapov P., Hansen M.C., Laestadius L., Turubanova S., Yaroshenko A., Thies C., Smith W., Zhuravleva I., Komarova A., Minnemeyer S., Esipova E., The last frontiers of wilderness: Tracking loss of intact forest landscapes from 2000 to 2013, Scientific Advances, 2017, Vol. 3, Iss. 1, p. e1600821.

URL:https://doi.org/10.1126/sciadv.1600821

Poveda G., Jaramillo L., Vallejo L.F., Seasonal precipitation patterns along pathways of South American low-level jets and aerial rivers, Water Resources Research, 2014, Vol. 50, Iss. 1, pp. 98-118. URL: https://doi.org/10.1002/2013WR014087

Pradhan R., Singh N., Singh R.P., Onset of summer monsoon in Northeast India is preceded by enhanced transpiration, Scientific Reports, 2019, Vol. 9, p. 18646.

URL: https://doi.org/10.1038/s41598-01955186-8

Romanovskaya A.A., Federici S., Kvota na vybrosy i rol' lesnogo sektora $\mathrm{V}$ nacional'nyh objazatel'stvah Rossijskoj Federacii $\mathrm{v}$ novom klimaticheskom soglashenii (Emission allowances and the role of the forest sector in the national obligations of the Russian Federation in the new climate agreement) St.-Petersburg: Trudy Sankt Peterburgskogo nauchnoissledovatel'skogo instituta lesnogo xozyajstva, 2015, Iss. 1, pp. 20-38. URL: http://journal.spb-niilh.ru/pdf/12015/spbniilh-proceedings-1-2015-2.pdf 
Schmidt M.W.I., Torn M.S., Abiven S., Dittmar T., Guggenberger G., Janssens I.A., Kleber M., Kögel-Knabner I., Lehmann J., Manning D.A.C., Nannipieri P., Rasse D.P., Weiner S., Trumbore S.E., Persistence of soil organic matter as an ecosystem property, Nature, 2011, Vol. 478, pp. 49-56. URL: https://doi.org/10.1038/nature10386

Sheil D., Bargués-Tobella A., Ilstedt U., Ibisch P.L., Makarieva A., McAlpine C., Morris C.E., Murdiyarso D., Nobre A.D., Poveda G., Spracklen D.V., Sullivan C.A., Tuinenburg O.A., van der Ent R.J., Forest restoration: Transformative trees, Science, 2019, Vol. 366, Iss. 6463, pp. 316-317. URL:https://doi.org/10.1126/science.aay 7309

Sheil D., Dangerous giants? - Large herbivores, forest feedbacks and climate tipping points, Russian Journal of Ecosystem Ecology, 2020, Vol. 5, Iss. 3. URL: https://doi.org/10.21685/2500-05782020-3-4

Sheil D., Forests, atmospheric water and an uncertain future: the new biology of the global water cycle, Forest Ecosystems, 2018, Vol. 5, No. 19, pp.1-22. URL: https://doi.org/10.1186/s40663-018-0138-y

Sillitoe P., Losing ground? Soil loss and erosion in the highlands of Papua New Guinea, Land Degradation \& Development, 1993, Vol. 4, Iss. 3, pp. 143-166. URL: https://doi.org/10.1002/ldr.3400040305

Smirnova O.V., Aleynikov A.A., Smirnov N.S., Lugovaya D.L., Pionovaja tajga (Peony taiga), Priroda, 2014, No. 2, pp. 5463. URL: https://elementy.ru/nauchnopopulyarnaya biblioteka/434360/Pionovay a tayga

Smith P., Soussana, J.-F., Angers D., Schipper L., Chenu C., Rasse D.P., Batjes N.H., van Egmond F., McNeill S., Kuhnert M., AriasNavarro C., Olesen J.E., Chirinda N., Fornara D., Wollenberg E., Álvaro-Fuentes J., Sanz-Cobena A., Klumpp K., How to measure, report and verify soil carbon change to realize the potential of soil carbon sequestration for atmospheric greenhouse gas removal, Global Change Biology, 2020, Vol. 26, Iss. 1, pp. 219-241. URL: https://doi.org/10.1111/gcb.14815

Tsvetkov M.A., Izmenenie lesistosti evropejskoj Rossii s konca XVII stoletija po 1914 god (Change in forest cover in European Russia from the end of the 17th century to 1914). M.: USSR Academy of Sciences, 1957, 213 p.

Turubanova S.A., Krylov A.M., Potapov P.V., Tyukavina A.Yu., Forest dynamics in Eastern Europe (1985-2012) using Landsat data archive, Russian Journal of Ecosystem Ecology, 2017, Vol. 2, Iss. 1. URL: https://doi.org/10.21685/2500-0578-20171-3

Wardle D.A., Jonsson M., Bansal S., Bardgett R.D., Gundale M.J., Metcalfe D.B., Linking vegetation change, carbon sequestration and biodiversity: insights from island ecosystems in a long-term natural experiment, Journal of Ecology, 2012, Vol. 100, Iss. 1, pp. 16-30.

URL: $\quad$ https://doi.org/10.1111/j.13652745.2011.01907.x

Watson J.E.M., Evans T., Venter O., Williams B., Tulloch A., Stewart C., Thompson I., Ray J.C., Murray K., Salazar A., McAlpine C., Potapov P., Walston J., Robinson J.G., Painter M., Wilkie D., Filardi C., Laurance W.F., Houghton R.A., Maxwell S., Grantham H., Samper C., Wang S., Laestadius L., Runting R.K., Silva-Chávez G.A., Ervin, J., Lindenmayer D., The exceptional value of intact forest ecosystems, Nature Ecology \& Evolution, 2018, Vol. 2, Iss. 4, pp. 599-610. URL: https://doi.org/10.1038/s41559-018-0490-X

Winckler J., Lejeune Q., Reick C.H., Pongratz J., Nonlocal effects dominate the global mean surface temperature response to the 
biogeophysical effects of deforestation, Geophysical Research Letters, 2019a, Vol. 46, Iss. 2, pp. 745-755. URL: https://doi.org/10.1029/2018GL080211

Winckler J., Reick C.H., Bright R.M., Pongratz J., Importance of surface roughness for the local biogeophysical effects of deforestation, Journal of Geophysical Research: Atmospheres, 2019b, Vol. 124, Iss. 15, pp. 8605-8618. URL: https://doi.org/10.1029/2018JD030127

Wright J.S., Fu R., Worden J.R., Chakraborty S., Clinton N.E., Risi C., Sun Y., Yin L., Rainforest-initiated wet season onset over the southern Amazon, Proceedings of the National Academy of Sciences U.S.A., 2017, Vol. 114, Iss. 32, pp. 8481-8486. URL:https://doi.org/10.1073/pnas.1621516114

Translated from Russian by the authors.
Zamolodchikov D.G., Kobjakov K.N., Kokorin A.O., Aleynikov A.A., Shmatkov N.M., Les i klimat (Forest and Climate). M.: World Wide Fund for Nature, 2015, 40 p.

Zelinka M.D., Myers T.A., McCoy D.T., PoChedley S., Caldwell P.M., Ceppi P., Klein S.A., Taylor K.E., Causes of higher climate sensitivity in CMIP6 models, Geophysical Research Letters, 2020, Vol. 47, Iss.1, p. e2019GL085782.

URL: https://doi.org/10.1029/2019GL085782

Zhou G., Liu S., Li Z., Zhang D., Tang X., Zhou C., Yan J., Mo J., Old-growth forests can accumulate carbon in soils, Science, 2006, Vol. 314, Iss. 5804, pp. 1417. URL: https://doi.org/10.1126/science.1130168 